\section{Temperature and Duration of Pretreatment Effects on Growth and Development of Geraniums}

\author{
Serge Gagnon and Blanche Dansereau \\ Département de Phytologie, Pavillon Comtois, Université Laval, Québec, \\ Qué. G1K 7P4 Canada
}

Additional index words. Pelargonium $\times$ hortorum, cold pretreatment, night temperature, split-night temperature

\begin{abstract}
Geranium seedlings (Pelargonium xhortorum Bailey 'Smash Hit Red') were given various cold pretreatments $(\mathrm{CP})$ to obtain more rapid adaptation to constant or split-night temperature regimes. The six following $C P$ were used: either $13 \mathrm{C}$ or $17 / 13 \mathrm{C}$ for 5, 10, or 15 days. The effect of these $C P$ given at seedling stage was compared with that of control plants held at $17 \mathrm{C}$ at night. The $\mathrm{CP}$ did not significantly increase the time to first visible flower buds or to anthesis. The number of flowering stems, plant height, shoot dry weight, and leaf area of control plants were not significantly different from plants receiving $\mathrm{CP}$.
\end{abstract}

During late fall and throughout the winter months, $\approx 70 \%$ of greenhouse heating costs in northern latitudes occur during the night (Lussier, 1981). Reducing the difference between inside greenhouse temperature and outside temperature is an excellent means of reducing energy consumption and production costs for geraniums and other pot plants.

Recent studies have shown that low night temperature (LNT) used throughout all production stages results in delays in time from sowing to anthesis (Armitage et al., 1981; Quatchak et al., 1986; Tsujita, 1982; White and Warrington, 1988). The split-night temperature (SNT) method, whereby the temperature is lowered during only part of the night, has enabled scientists to resolve this problem with bedding plants (Shedlosky and White, 1987) and flowering pot plants (White and Warrington, 1984). Low-night-temperature treatments applied at the seedling stage [as a cold pretreatment $(\mathrm{CP})$ ] might also provide considerable energy saving without prolonging production time. Seedling geraniums are less affected by temperature from this stage to the first visible flower buds than more advanced plants (Armitage, 1985; Hellgren, 1984).

The purpose of this study was to determine the influence of various $\mathrm{CP}$ and then duration on the growth and flowering of geranium to adapt these plants to lower production temperature regimes.

Seeds of geranium 'Smash Hit Red' were sown 3 Jan. 1986 in a substrate consisting of 1 peat moss : 1 vermiculite $(\mathrm{v} / \mathrm{v})$. Seed-

\footnotetext{
Received for publication 23 Dec. 1988. Accepted for publication 20 Sept. 1991. We acknowledge Agriculture Québec for its financial support and thank Tommy Vong Jensen and Alain Ménard for their technical assistance. Thanks are also extended to André Gosselin and Jacques-Andri Rioux for help in revising this paper. The cost of publishing this paper was defrayed in part by the payment of page charges. Under postal regulations, this paper therefore must be hereby marked advertisement solely to indicate this fact.
}

lings were transplanted 17 Feb. 1987 into 0.5-liter pots (IO-cm standard pots) containing a Cornell Peat Lite A mix (Boodley and Sheldrake, 1973) and Osmocote (14N-6.7P$11.6 \mathrm{~K})$ incorporated at a rate of $3 \mathrm{~kg} \cdot \mathrm{m}^{-}{ }^{3}$. During this study, plants were given four supplemental liquid fertilizations $(250 \mathrm{ml} / \mathrm{pot})$ using $20 \mathrm{~N}-8.8 \mathrm{P}-16.6 \mathrm{~K}$ to provide $200 \mathrm{ppm}$ $\mathrm{N}$. One month before the end of the study, the plants were transplanted into 1.75-liter pots $(15-\mathrm{cm}$ standard pots).

Treatments were provided in three identical and connected greenhouse compartments from 19 Feb.-6 Mar. 1987. During $\mathrm{CP}$, day temperature in each greenhouse compartment was $20 \pm 2.0 \mathrm{C}$. Control plants were placed in the first compartment, where a high of $17 \pm 1.5 \mathrm{C}$ was maintained between 1700 and $0800 \mathrm{HR}$. In the second compartment, plants received a CP consisting of $17 \pm 1.5 \mathrm{C}$ nights, from 1700 to $0030 \mathrm{HR}$ and then $13 \pm 1.5 \mathrm{C}$ from 0030 to $0800 \mathrm{HR}$ [split night temperature (SNT)]. One group of plants was given this treatment for 15 days, a second group for 10 days, and a third group for only 5 days. In the third compartment, plants received a $\mathrm{CP}$ of $13 \pm 1.5 \mathrm{C}$ between 1700 and 0800 HR for 5, 10, or 15 days. All plants having received one of the $\mathrm{CP}$ during 5 or 10 days were then placed in the first compartment (17C from 1700 to $0800 \mathrm{HR}$ ) with control plants before the start of CP. Following the treatments, all plants were distributed in five blocks with two plants of all $\mathrm{CP}$ and a control in each, and placed in a double-layer polyethylene-covered greenhouse. Thermocouples placed at canopy height were connected to a Honeywell recorder (Electronick 112 Type T, Honeywell, Minneapolis). The daytime air temperature in the greenhouse was $20 \pm 2.0 \mathrm{C}$ and at night it was $17 \pm 1.5 \mathrm{C}$ from 1700 to $0030 \mathrm{HR}$ and then $13 \pm 1.5 \mathrm{C}$ from 0030 to 0800 HR during the last part of the experiment.

The number of days to first visible flower buds (S-mm diameter) and anthesis were recorded for all plants. The growth and de- velopment variables (plant height, shoot dry weight, and leaf area) were recorded for all plants when $50 \%$ of the plants in each treatment reached anthesis. The shoots of each plant were cut at the soil level and the root system cleaned in a water bath and dried with an air hose. The shoot and root systems, after being dried for $48 \mathrm{~h}$ in a hot-air oven (70C), were each weighed. Leaf area was measured using a leaf area meter (LI-COR 3000; LI-COR, Lincoln, Neb).

A complete-block design with five replications was used. All seven treatments (control and six CP) were placed in each block. Each experimental unit had two plants. Multiple comparisons were done according to Duncan's new multiple range test.

The time to the first visible flower bud stage (57 to 60 days) or to anthesis (85 or 86 days) was similar for all plants, regardless of whether they received a CP treatment. These results are in agreement with the theory proposed by Armitage et al. (1981) for seed-propagated geraniums. According to these authors, the length of time between sowing and first visible flower bud stage is least affected by temperature. However, temperature will greatly affect the length of time from first visible flower buds to anthesis. During this latter stage, all the plants received the same night temperature (NT) regime, $17 / 13 \mathrm{C}$ in our experiment. Tsujita (1982) showed that flowering of geraniums was delayed when they received a lower NT regime throughout all production stages.

Cold pretreatment did not cause a significant variation in the number of flowering stems (2.9 to 3.7) when compared with control plants, although the control had the fewest (Table 1). Our results are in agreement with those of Hellgren (1984). Tsujita (1982) has shown that $\mathrm{CP}$ can cause an increase in the number of axillary stems and thus increase the number of flowering stems. Nevertheless, the CP we used were not applied long enough to produce significant differences. Sénécal and Dansereau (1987) also obtained a nonsignificant increase in number of flowers per plant by using a LNT regime to produce Gerbera jamesonii $\mathrm{H}$. Bolus ex Hook. in the spring.

Plant height was not significantly affected by the different $\mathrm{CP}$ when compared with the control plants (Table 1). This same tendency was observed by White and Warrington

Table 1. Effects of different cold pretreatments (CP) (temperature and duration) on the growth of Pelargonium $\times$ hortorum 'Smash Hit Red'.

\begin{tabular}{|c|c|c|c|}
\hline \multicolumn{2}{|c|}{ Treatments } & \multirow{2}{*}{$\begin{array}{c}\text { Plant } \\
\text { ht } \\
(\mathrm{cm})\end{array}$} & \multirow{2}{*}{$\begin{array}{c}\text { Shoot } \\
\text { dry wt } \\
(\mathrm{g})\end{array}$} \\
\hline $\begin{array}{l}\text { Night temp } \\
\left({ }^{\circ} \mathrm{C}\right)\end{array}$ & $\begin{array}{c}\text { Duration } \\
\text { (days) }\end{array}$ & & \\
\hline $13(\mathrm{CP})$ & 5 & $22.2 b^{2}$ & $20.11 \mathrm{ab}$ \\
\hline 13 (CP) & 10 & $22.7 \mathrm{~b}$ & $19.61 \mathrm{~b}$ \\
\hline 13 (CP) & 15 & $22.7 \mathrm{~b}$ & $20.21 \mathrm{ab}$ \\
\hline $17 / 13$ (CP) & 5 & $22.0 \mathrm{~b}$ & $19.71 \mathrm{~b}$ \\
\hline $17 / 13(\mathrm{CP})$ & 10 & $25.0 \mathrm{a}$ & $21.66 \mathrm{a}$ \\
\hline $17 / 13$ (CP) & 15 & $23.7 \mathrm{ab}$ & $21.05 \mathrm{ab}$ \\
\hline 17 (control) & 15 & $23.3 \mathrm{ab}$ & $20.84 \mathrm{ab}$ \\
\hline
\end{tabular}

${ }^{2}$ Means separation in column by Duncan's new multiple range test, $P=0.05$. 
(1984). However, if we compare the means of $\mathrm{CP}$ receiving $\mathrm{NT}$ of $17 / 13 \mathrm{C}$ during 10 days with those of three $\mathrm{CP}$ receiving NT of $13 \mathrm{C}$, the latter were more compact. Tsujita (1982) has shown this same response, also using geraniums.

The CP did not adversely affect shoot dry weight (Table 1); however, Hellgren (1984) obtained contrasting results. These differences might simply be due to the different experimental conditions. This previous work was carried out in a growth chamber where the photosynthetic photon flux of 64 and 140 $\mu \mathrm{mol} \cdot \mathrm{m}^{-2} \cdot \mathrm{s}^{-1}$ was considerably less than natural light intensities in the greenhouse.

Cold pretreatment did not affect the leaf area (range $\approx 1900-2200 \mathrm{~cm}^{2}$ ). White and Warrington (1984) obtained a decrease in leaf area while using LNT. However, these authors used NT regimes instead of CP throughout the entire experiment. If there is a reduction in new structure formation during a $\mathrm{CP}$, as reported by Longuenesse (1978) during LNT regimes, then those plants similarly treated would become more efficient under a SNT regime (Gent et al., 1979).

The results of this study indicate that it is possible to acclimate geraniums propagated by seed to SNT regimes by using pretreatments. Cold pretreatments did not cause a delay in the number of days to first visible flower buds and anthesis. Moreover, marketable quality of plants can also be improved using this method. A LNT regime applied at an early growth stage led to a slight increase in the number of flowering stems as well as more compact plants. The reduction in the plant height, as a result of this method, would mean less need for growth regulators. From a commercial view point, this method would lower energy costs by using $\mathrm{CP}$ for 15 days or even longer. For example, the use of $13 \mathrm{C}$ instead of $17 \mathrm{C}$ as a pretreatment results in a $22 \%$ reduction of heating costs during a period when the outside average temperature is -6.5 (Sénécal, 1984).

\section{Literature Cited}

Armitage, A.M. 1985. Hybrid geraniums-Factors affecting flowering. Bedding Plant Inc. News, Jan. 1985: 10-12.

Armitage, A.M., W.H. Carlson, and J.A. Flore. 1981. The effect of temperature and quantum flux density on the morphology, physiology and flowering of hybrid geraniums. J. Amer. Soc. Hort. Sci. 106:643-647.

Boodley, J.W. and R. Sheldrake. 1973. Cornell peatlite mixes for commercial plant growing. Info. Bul. 43, New York State College Agr. and Life Sci., Cornell Univ. Ithaca, N.Y. p.1-8.

Gent, M.P.N., J.H. Thorne, and D.E. Aylor 1979 Split-night temperature in a greenhouse: the effects on the physiology and growth of plants. Conn. Agr. Expt. Sta. Bul. New Haven 781.

Hellgren, O. 1984. Growth and development of Pelargonium zonale hybr. II. Acclimation to temperature. PhD Diss., Swedish Univ. Agr. Sci., Alnarp.

Longuenesse, J.J. 1978. Temperature nocturne et photosynthèse: I. Etude bibliographique. Ann. Agron. 29:525-539.

Lussier, J.L. 1981. Essais d'une couverture thermale. Bulletin d'information. Centre de dével- oppement des cultures abritées du Quebec. Janvier-Février.

Ouatchak. D.J.. J.W. White. and E.J. Holcomb. 1986. Temperature, supplemental lighting, and chlormequat chloride effects on flowering of geranium seedlings. J. Amer. Soc. Hort. Sci. 111:376-379

Sénécal, M. 1984. Influence de la temperature nocturne sur le chrysanthème de serre. Travail d'écophysiologie végétale. Mars 1984.

Sénécal, M. and B. Dansereau. 1987. Influence de la temperature nocturne et d'un appoint de lumière sur la croissance et le développement du Gerbera et du Calendula. Can. J. Plant Sci. 67:871-879.

Shedlosky, M.E. and J.W. White. 1987. Growth of bedding plants in response to root-zone heating and night temperature regimes. J. Amer. Soc. Hort. Sci. 112:290-295.

Tsujita, M.J. 1982. Supplemental high pressure sodium lighting and night temperature effects on seed geraniums. Can. J. Plant Sci. 62:149153 .

White, J.W. and I.J. Warrington. 1984. Effects of split-night temperatures, light, and chlormequat on growth and carbohydrate status of Pelargonium xhortorum. J. Amer. Soc. Hort. Sci. 109:458-463.

White, J.W. and I.J. Warrington. 1988. Temperature and light integral effects on growth and flowering of hybrid geraniums. J. Amer. Soc. Hort. Sci. 113:354-359. 